\title{
ACUTE AND CHRONIC ANAESTHETIC ACTIONS ON LEUKOCYTES*
}

\author{
DaviD L. BRuce, M.D. $\dagger$
}

IN THIS PAPER, an attempt will be made to review some known actions of anaesthetics on circulating or tissue leukocytes. From these reports, we may question the clinical consequences of such actions, if they occur in man. This is intended not to be an inclusive review of this area, but rather a selective overview to support the subsequent speculations.

Leukocyte is defined as, "any colorless, amoeboid cell mass, such as a white blood corpuscle, pus corpuscle, lymph corpuscle or wandering connective tissue cell." This definition is implicit in the title of this article, which will discuss effects on bone marrow, circulating white blood cells and fixed, lymphoid tissue. For convenience, the discussion will be divided into three sections: acute effects; chronic effects; and, finally, possible clinical consequences.

\section{Acute Anaesthetic Actions}

Long ago, biologists used ether or chloroform as a laboratory tool to inhibit cell division reversibly. A brief glimpse of earlier work will assist in the assignment of recent studies to their proper perspective. Claude Bernard felt that changes of state in the intracellular colloids could account for anaesthetic inhibition of cell division. ${ }^{2}$ This theory was supported strongly by L.V. Heilbrunn ${ }^{3}$ in numerous studies of anaesthetic effect on amoebae. Goldacre observed similar changes in amoebae but ascribed the cause to effects on their cell membranes. ${ }^{4}$ We studied effects of ether and halothane on the giant amoeba, Chaos chaos ${ }^{5}$ and favored the idea of an intracellular site of action by these agents. Andersen ${ }^{6}$ advanced the "C-mitosis" theory of Ostergren ${ }^{\tau}$ which held that inhibition of cell division was due to an effect on the contractile mechanism of the mitotic spindle. This was extended by Allison and $\mathrm{Nunn}^{8}$ to include not only the microtubular components of the mitotic spindle but also the microtubules found in axons, which they suspected were disrupted structurally by halothane. Recently, Hinkley and Green have found no correlation between axonal microtubular makeup and the ability of these nerves to conduct electrical impulses. ${ }^{9}$

The common thread running through these studies, spanning almost 100 years, is that volatile anaesthetics somehow alter reversibly the intracellular milieu so as to inhibit the normal function of that cell. Taking this as a useful definition of cell narcosis, the effects of anaesthetics on haematopoietic tissue may then be analyzed in light of the known functions of these cells. Fortunately, we find that these functions are few as compared, say, to a liver cell. Using the broadly defined term,

\footnotetext{
"Supported in part by USPHS Grant GM 15420.

†Associate Professor, Department of Anaesthesia, Northwestern University Medical School, 303 East Chicago Avenue, Chicago, Illinois 6061l. Recipient of USPHS Career Development Award 5 K3 GM 35264.
}

Canad. Anaesth. Soc. J., vol. 20, no. 1, January 1973 
leukocyte, we know that these cells do one or more of the following: they divide when signalled to do so; they exhibit locomotor ability; they engulf particles (phagocytosis) and they are able to migrate through tiny openings in capillaries to go from an intravascular to extravascular locus (diapedesis). Anaesthetics have been found to affect acutely each of these functions in some leukocytes.

Normally, circulating leukocytes do not divide. To assay anaesthetic action on this function, studies of bone marrow have been done by many investigators. Following the finding that leukopenia developed in patients given nitrous oxide as part of their treatment for tetanus, ${ }^{10}$ Green and Eastwood reported severe bone marrow depression in rats given $\mathrm{N}_{2} \mathrm{O}$ for prolonged periods. ${ }^{11}$ Unaware of this work at that time, Bruce and Koepke were studying the effect on bone marrow of continuous exposure of rats to 0.45 per cent halothane in air for periods from 24 to 115 hours. ${ }^{12}$ Our study was prompted by the earlier studies cited, where the amoeba was rendered motionless by this anaesthetic. Since amoebae and leukocytes are phylogenetic analogues, it seemed appropriate to do this study to see if immobility impaired cell division. In contrast to the $\mathrm{N}_{2} \mathrm{O}$ effect on marrow, halothane did not diminish the overall cellularity. Instead, the ratio of dividing to maturing cells was increased, suggesting a damming up of dividing cells of the myeloid series. ${ }^{13}$ The eventual effect on peripheral neutrophil count was the same; both anaesthetics lowered it significantly. Similar studies showed that leukopenia could be produced by other inhalational agents. ${ }^{14,15}$

In all these studies, the anaesthetic had to be given continuously for long periods to achieve a change in bone marrow which was reflected in number of circulating cells. The actual duration of administration was in excess of the time taken for surgical operations. Consequently, the depression is felt by many to represent only an interesting laboratory phenomenon. Later, we shall speculate about situations where it might be of practical importance.

If amoebae are rendered so immobile by anaesthetics that they cease ingesting foodstuffs by phagocytosis, why would this not also happen to mammalian phagocytic cells such as polymorphonuclear neutrophils? So reasoning, we studied the ability of rabbits anaesthetized with ether to mobilize neutrophils into areas of abraded skin and to phagocytize starch particles placed there. We were unable to quantitate our results, so they were never published; but it was clear that few phagocytes ingested the particles in the anaesthetized animal, compared to controls done in the same animal when it was awake. A more quantitative study in mice was published, which showed that halothane anaesthesia caused a reduction from 24.6 to 2.7 Salmonella ingested per peritoneal neutrophil, four hours following injection of the bacteria. ${ }^{16}$ While preparing the bibliography to this paper, we discovered the report of Graham, ${ }^{17}$ who in 1904 showed the same phenomenon in neutrophils from patients under ether anaesthesia. Once again, a study thought to be original turned out not to be.

During a period of cellular immobilization, transvascular diapedesis of leukocytes should be inhibited. A study ${ }^{18}$ verified that this was the case in the mouse, that it was immediately reversible upon cessation of anaesthetic administration, and a subsequent unpublished study in our laboratory has shown this not to be due to decreased capillary permeability. Intravenous Evans Blue appeared in the 
peritoneal cavity of the mouse, following intravenous injection, at the same rate in the presence of halothane anaesthesia that it did in awake animals.

We have spoken of depression of division in bone marrow cells in the mainstream of the dividing cell population. Unlike some tissues, bone marrow has a reserve population of cells which are not actively in the cycle of cell division but which are capable of being recruited into cycle upon receipt of an appropriate signal. The nature of this signal, biochemically, is unknown, but the clinical cases where it will be active are well known. In the presence of severe infection, immature neutrophils ("stabs" or "bands") are found in the circulation. This indicates a speed-up in the marrow myeloid series assembly line. Following a large but not lethal dose of ionizing radiation the marrow also speeds up to replace quickly the population of its decimated members. Cancer chemotherapy kills innocent bystander cells in the marrow if they happen to be in the susceptible segment of their cycle when they contact the drug. In all these cases, the "stem" cells will enter the divisional cycle to replenish the marrow. We know, clinically, that this happens. Animal studies have verified the reality of this small, but critical population of marrow reserve cells. ${ }^{19,20}$

Recent studies of anaesthetic effect on these cells have shown that normal stem cells are protected from chemotherapeutic drugs by halothane and, to a lesser extent, by nitrous oxide. ${ }^{21}$ The most reasonable explanation for this finding is that the anaesthetic blocks the entrance of the cell into cycle, where it would be vulnerable to the toxic action of the chemotherapeutic drug. Fortunately, a laboratory model exists to test this hypothesis, where the cells do not normally divide but can be induced to do so by the addition of a known chemical signal. This is the human lymphocyte culture to which is added a plant extract called phytohaemagglutinin (PHA), following which the cells enlarge, synthesize RNA, protein, DNA and then divide. This reaction is blocked in a linear fashion by anaesthetic doses of halothane. ${ }^{22,23}$ This supports strongly the hypothesis of halothane action on resting cells and raises the question of the relevance of this to the effect of anaesthetics on the immune response.

Immunity is known to be influenced adversely by anaesthetics and we have reviewed this subject in detail. ${ }^{24}$ For present purposes it seems sufficient to point out that proliferation of specifically sensitized cells of lymphoid tissue, upon contact with the appropriate antigen, is the key event in the immune response. The similarity of this to the in vitro PHA-lymphocyte reaction is the basis for the recent wave of interest in lymphocyte culture techniques as a tool for study of immunological problems. Now that we know lymphocytes are prevented from reacting to PHA in the presence of one anaesthetic, we may be well along in establishing the basis for the general phenomenon of immunosuppression by anaesthetics.

\section{Chronic Effects}

What do we mean by "chronic effects?" Do we mean long term effects of a relatively brief inhalation of anaesthetic, or the result of chronic, long-term inhalation? Are we speaking of high anaesthetic doses or low, sub-anaesthetic doses? All these are of interest, but little is known of many possible combinations of duration of anaesthesia, dose, and length of effect. An example of the first possi- 
bility mentioned above would be a patient who developed hepatic or renal dysfunction which persisted long after an anaesthesia was terminated. He would qualify as showing a "chronic effect." About these unfortunate few we shall say nothing at this time.

Let us instead consider the effects of long-term inhalation of anaesthetics. We have already considered the bone marrow depression caused by several days' inhalation of high concentrations of a variety of inhalational agents, in the section on acute effects. It was put there in order to facilitate discussion of all known acute effects on leukocytes. Very little animal work has been done to establish the effects of long-term inhalation of low-dose anaesthetics on leukocytes. We exposed rats to 100 parts per million ( $\mathrm{ppm}$ ), or 0.01 per cent halothane in air for seven hours daily, five days per week, for several months. ${ }^{25}$ Compared to littermate controls breathing only air, these rats showed no striking change in peripheral blood counts or bone marrow histology. Their spleens were twice the size of those of the control rats, yet were histologically normal. In another study, mice exposed to 0.1 per cent halothane in air for the same daily schedule as in the rat study, over a period of 15 weeks, showed no change in marrow histology or blood counts, and their spleens were of normal size although a few exhibited foci of lymphoid hyperplasia. ${ }^{26}$ Currently in progress is a study where mice are being exposed on this same schedule to $15 \mathrm{ppm}$ halothane in air $(0.0015$ per cent $)$ and splenic histology will be done at the end of this study. This $15 \mathrm{ppm}$ concentration corresponds closely to levels we have measured in the ambient air of our operating rooms ${ }^{27}$ and we are awaiting with interest the outcome of this study. There have been no published reports of experimental immunity models tested during prolonged exposure to small anaesthetic amounts.

\section{Possible Clinical Consequences}

Building on the base of the foregoing fragmentary information, we may speculate about possible consequences in the clinical setting. Most information exists concerning acute effects of anaesthetics. Since this is the way we administer anaesthesia to patients, we should be most interested in this aspect of the problem. In a recent brief publication ${ }^{28}$ we have suggested that inhibition of cell division of marrow leukocytic precursors probably isn't harmful to the healthy patient. We see today, in increasing number, patients with relative bone marrow failure secondary to radiation, chemotherapy or immunosuppressive therapy. ${ }^{29}$ What about them?

A review ${ }^{30}$ of the kinetics of granulopoiesis in man indicates that the total blood granulocyte pool turns over 2.3 times daily. When a cell disappears from the blood it does not return, and a granulocyte stays in circulation only seven hours. To sustain this high turnover, a depot of myeloid marrow cells is constantly replenishing the supply through a series of divisions and subsequent maturation stages which end with the mature granulocyte. Anaesthetic interference with the production of these precursors, if they are already diminished in number by disease or drugs, might result in a deficiency of neutrophils several days later.

Acutely, then, we may unknowingly contribute to the chance of infection by administering anaesthetics which could do the following: (1) temporarily inhibit 
the egress of phagocytes from the circulation to the sites of bacterial contamination occurring during operation; (2) diminish the capacity for phagocytosis of the cells which do encounter these bacteria; (3) retard the rate of flow of marrow precursors, resulting in a relative decrease in neutrophil numbers several days later. In the patient with minimal marrow reserve, a long anaesthetic could conceivably favor the beginning bacterial growth which, in the face of inadequate host defenses over the next few days, could result in wound infection or pneumonia. In addition to impairment of these cellular defenses we must consider the likelihood of acute immunosuppression occurring during anaesthesia, with attenuation of the humoral responses which aid these cellular ones. In the review cited earlier ${ }^{24}$ we pointed out many examples where a variety of anaesthetics did depress the immune response. In addition to a deleterious effect on defenses against bacterial infection, there remains to consider the virtually unexplored topic of viral infections. Might not anaesthetic depression of the immune response alter both the outcome and the clinical course of a viral disease? In the study of halothane effect on Salmonella peritonitis in mice, ${ }^{16}$ the eventual death rate was the same for anaesthetized and unanaesthetized animals, but the time of death was significantly sooner for those receiving halothane. In other words, the natural history of that bacterial infection was changed to a more acute course. We know little if anything about comparable effects on viral processes. Yet, today we are reassured frequently that cases of acute hepatic necrosis could not be viral in aetiology, since they do not follow the normal clinical course of viral hepatitis. Until the time an animal model is generally available to study this disease and the influence of anaesthesia on its course, we can only speculate that its course could be different in the postoperative patient than in the average medical patient with hepatitis.

Restricting this discussion to cellular elements of the blood, bone marrow and lymphoid tissue, we have little information to indicate a deleterious effect of longterm inhalation of traces of anaesthetics. A twenty year retrospective study of causes of death of anaesthesiologists in the United States and Canada ${ }^{31}$ revealed a normal death rate from leukaemia but an increased mortality from malignancies of the reticuloendothelial and lymphoid tissues. So far we have been unable to produce these in animals, but there are suggestions in the studies cited earlier that anaesthetic-lymphoid interaction occurs at low levels of exposure. Patches of lymphoid hyperplasia in spleens of mice exposed to 0.1 per cent halothane; spleens double the size of paired controls in rats breathing 0.01 per cent halothane; these are fragmentary findings encouraging us to look further but promising no immediate answer to the question.

It is now well known that chemical immunosuppression in recipients of organ transplants has led to an increased incidence of lymphoid malignancies in these patients. $^{32}$ Could anaesthetists, by occupational exposure to anaesthetics, be chronically immunosuppressed and, therefore, susceptible to such tumor development? We have recently studied several staff anaesthetists at our institution, using PHA stimulation of cultures of their lymphocytes to assess the apparent adequacy of their immune response. All tested normally; in fact, somewhat more actively than non-anaesthetist control subjects. We must remember, though, that the increased death rate from these malignancies still only represented one or two 
deaths per several thousand anaesthetists in any given year. It is clearly impractical to study a large enough population of anaesthetists to answer the question of whether a rare individual is immunosuppressed from occupational exposure to these agents.

Virtually all our studies have been done with halothane. This must not be misinterpreted to mean we suspect halothane is responsible for toxic effects and other agents are not. Simply stated, we decided some time ago to restrict ourselves to study in detail the effects of one agent on many different processes, rather than applying a host of anaesthetic agents to only a few experimental situations. We work in this fashion with the belief that some day we will have enough information about one agent to design the expermentum crucis which we can then employ for all the anaesthetics in use at that time.

Several thoughts sustain our interest in this topic. First, new injectable drugs are periodically predicted to replace inhalational agents, but to date these predictions have not materialized. Our patients who reject regional techniques on the grounds they wish to be asleep will doubtless decline the offer of acupuncture. Inhalational anaesthesia, for the foreseeable future, is here to stay. It may well be that no agent will affect only the nervous system, producing unconsciousness but no other cellular effects in the body. If our agents have an irreducible degree of toxicity, we can minimize exposure of the patient to anaesthesia only by encouraging swift surgery. At the same time, we can virtually eliminate our own exposure to trace anaesthetics in operating room air by installation of scavenging systems to clear the air of overflow gases and vapors. ${ }^{33}$

In this discussion, we have periodically pointed out historical comparisons to more modern studies. In closing, we can describe one anaesthetic agent which might have come into use except for unpleasant side effects, and what was learned of this agent during subsequent studies over many years. This agent, used by both Simpson and Snow, caused patients to complain of tinnitus so severely that these pioneers in our specialty abandoned its use.$^{34}$ Its anaesthetic concentration in air is about 1 per cent, similar to many agents we now use. ${ }^{35}$ It is a volatile hydrocarbon which has a profound bone marrow depressing effect when given over several days to rabbits, ${ }^{36}$ dogs ${ }^{37}$ and man. ${ }^{38,39}$ In tissue culture ${ }^{40}$ it caused a pattern of "maturation arrest" in explanted guinea pig marrow cells, very similar to the effects we described in rats given halothane. When inhaled chronically in low amounts, occupationally, it was thought to have resulted in 12 cases of leukaemia by $1939 .{ }^{41}$ The compound in question is benzene. To this day some haematologists question its causal relation to leukaemia, but it clearly has acute, subacute, and possibly chronic effects on leukocytes which resemble those we currently are finding with our modern anaesthetic agents. Only time will tell if these associated effects are obligatory due to a common mechanism in nervous system and other cells. In the meantime, prudence suggests we avoid unnecessary exposure of our patients and of ourselves to the ethereal tools of our trade.

\section{RÉSUMÉ}

\section{Actions Anesthésiques Aigues}

Les données couramment émises sur des études couvrant presqu’un siècle, indi- 
quent, que les substances anesthésiques volatiles altèrent quelque peu, de façon reversible le milieu intra cellulaire, de sorte que la fonction normale de la cellule soit inhibée.

En prenant cet énoncé comme une définition de la narcose cellulaire, les effets des agents anesthésiques sur le tissue hématopoiétique peuvent être analysés à la lumière des fonctions connues de ces cellules.

Ces fonctions cellulaires heureusement sont peu nombreuses comparées à celle de la cellule hépatique par exemple.

Les leucocytes ont différentes propriétés : division, phagocytose, abilité locomotrice, diapedèse et les agents anesthésiques peuvent affecter chacune d'elles de façon aigue.

\section{Effets chroniques}

Grace à des expériences faites sur de petits animaux, on a pu établir les effets de l'inhalation à petites doses sur les leukocytes en exposant des rats à une concentration de 0.01 pour cent de halothane dans l'air, 7 heures par jour et 5 jours par semaine durant plusieurs mois.

Comparé au groupe controlé ne respirant que de l'air ces animaux ne présentèrent pas de changement notable dans le décompte cellulaire sanguin périphérique ou dans l'histologie de la moelle osseuse. Leurs rates atteignaient deux fois le volume de celles des animaux de controle sans aucune altération histologique. Dans une autre étude, des souris furent exposées à une concentration de 0.1 pour cent d'halothane selon la même schédule précédente, sur une période de 15 semaines, sans afficher aucun changement histologique tant au niveau de la moelle que du sang périphérique. Leurs rates étaient de volume normal avec quelques foyers d'hyperplasie lymphoide chez un petit nombre d'entre-elles.

Une étude est actuellement en cours où des souris sont exposées à une concentration de 0.0015 pour cent d'halothane dans l'air soit 15 parties par million (ppm) dont l'histologie splénique sera déterminée à la fin de l'étude.

Cette concentration de (15 ppm) correspond aux niveaux de l'air ambiant mésurés dans nos salles d'opération.

\section{Consequences chimiques possibles}

Nous basant sur cette information fragmentaire précitée nous pouvons spéculer au sujet des conséquences cliniques possibles. Lors d'une brève et récente publication nous avons suggéré que l'inhibition de la division cellulaire des précurseurs leucocytaires de la moelle ne causerait probablement aucun trouble chez le sujet en bonne santé. De plus en plus nous voyons des patients afficher des défaillances relatives de la moelle consécutives à la radiation, la chimiothérapie ou à la thérapie immunosuppressive. Qu'advient-il de ces patients?

De façon aigue on peut ouvrir la porte à l'infection en administrant des agents anesthésiques qui agissent de la façon suivante:

(1) Inhibition temporaire de la migration des phagocytes de la circulation aux sites de contamination bactérienne se produisant pendant l'opération

(2) Diminution de la capacité de phagocytose des cellules devant rencontrer ces bactéries. 
(3) Retard dans le rythme de production des précurseurs de la moelle résultant en une diminution relative dans le nombre des neutrophiles plusieurs jours après.

Chez le sujet avec une réserve minime de la moelle, un agent anesthésique utilisé sur une durée assez longue favoriserait un début de croissance bactérienne résultant en une infection de la plaie opératoire ou en une pneumonie. De plus la possibilité d'immunosuppression au cours de l'anesthésie avec atténuation des réponses humorales pourrait modifier le déclanchement de même que l'évolution clinique d'une affection virale.

Il est bien établi que l'immunosuppression chimique chez les porteurs d'organes transplantés a conduit à une incidence accrue de néoplasies lymphoides chez ces patients. Se pourrait-il que l'anesthésiste par l'exposition chronique aux substances anesthésiques soit susceptible à présenter de telles tumeurs?

Nous avons récemment étudié la réponse immunologique adéquate des membres de notre département en utilisant la stimulation au PHA des cultures de leurs lymphococytes. Les résultats se sont avérés tous normaux et même les réponses ont été plus actives que chez les sujets de controle non anesthésistes. Il est clairement impratiquable d'étudier une population d'anesthésistes assez suffisante pour répondre à la question, à savoir, que si l'un d'entre eux pourrait présenter des phénomènes d'immunosuppression à l'exposition chronique à ces agents du fait de son occupation.

\section{REFERENCES}

1. Dorland's Illustrated Medical Dictionary, 23rd edition. Philadelphia: W.B. Saunders Co. (1957), p. 746.

2. Bernard, C. Lecons sur les anesthesiques et sur l'asphyxie. Paris: Baillière (1875).

3. Heilbrunn, L.V. Colloid theories of narcosis. In Mecanisme de la Narcose, Paris: CNRS (1951), p. 163.

4. GoldACRE, R.J. The action of general anaesthetics on amoebae and the mechanism of the response to touch. Cambridge: University Press, Symp. Soc. Exp. Biol. VI: 128 (1952).

5. Bruce, D. \& Christiansen, R. Morphologic changes in the giant amoeba chaos chaos induced by halothane and ether. Exp. Cell Res. 40:544 (1965).

6. Andersen, N.B. The effect of CNS depressants on mitosis. Acta Anaesth. Scand. 10: Suppl. 22 (1966).

7. OsterGReN, G. Narcotized mitosis and the precipitation hypothesis of narcosis. In mecanisme de la narcose. Paris: CNRS (1951), p.77.

8. Axlrson, A.C. \& NunN, J.F. Effects of general anaesthetics on microtubules: a possible mechanism of anaesthesia. Lancet 2: 1326 (1968).

9. Hinkley, R.E., JR. \& GreEN, L.S. Effects of halothane and colchicine on microtubules and electrical activity of rabbit vagus nerves. J. Neurobiol, 2: 97 (1971).

10. Lassen, H.C.A., Henriksen, E., Neukirch, R., \& Kristensen, H.S. Treatment of tetanus. Severe bone marrow depression after prolonged nitrous oxide anesthesia. Lancet 1:527 (1956).

11. GREEN, C.D. \& Eastwood, D.W. Effects of nitrous oxide inhalation on hemopoiesis in rats. Anesthesiology 24: 341 (1963).

12. Bruce, D.L. \& KoEPKE, J.A. Changes in granulopoiesis in the rat associated with prolonged halothane anesthesia. Anesthesiology 27: 811 (1966).

13. Bruce, D.L., Koepke, J.A., \& Traurig, H.H. Studies of DNA synthesis in the halothane treated rat. In Fink, B.R. (Ed.), Toxicity of Anesthetics. Baltimore: Williams and Wilkins (1968), p. 123.

14. Aldrete, J.A. \& Virtue, R.W. Prolonged inhalation of inert gases by rats. Anesth. Analg. 46:562 (1967).

15. Aldrete, J.A. \& Virtue, R.W. Effects of prolonged inhalation of anesthetic and other gases on blood and marrow of rats. In, Fink, B.R. (Ed.), Toxicity of Anesthetics, Baltimore: Williams and Wilkins (1968), p. 105. 
16. BRUCE, D.L. Effect of halothane anesthesia on experimental salmonella peritonitis in mice. J. Surg. Res. 7: 180 (1967).

17. Granam, E.A. The influence of ether and ether anesthesia on bacteriolysis, agglutination and phagocytosis. J. Infect. Dis. 8: 147 (1911).

18. BRUCE, D.L. Effect of halothane anesthesia on extravascular mobilization of neutrophils. J. Cell. Physiol. 68: 81 (1966).

19. Lajtha, L.G., Gilbert, C.W., Ponteous, D.D., \& Alexanian, R. Kinetics of a bone marrow stem-cell population. Ann. N.Y. Acad. Sci. 113: 742 ( 1954).

20. BruCE, W.R. \& VALERIOTE, F.A. Normal and malignant stem cells and chemotherapy. In, The proliferation and spread of neoplastic cells. University of Texas, M.D. Anderson Hospital and Tumor Institute at Houston. Baltimore: Williams and Wilkins (1968), p. 409.

21. Bruce, D.L., LiN, H-S., \& Bruce, W.R. Effects of anesthetics on the response of normal and abnormal bone marrow cells to cytotoxic drugs. In, Fink, B.R. (Ed.), Cellular Biology and Toxicity of Anesthetics. Baltimore: Williams and Wilkins (1972), p. 251.

22. BRUCE, D.L. Halothane inhibition of phytohemagglutinin-induced transformation of lymphocytes. Anesthesiology 36: 201 (1972).

23. Cullen, B.E., Sample, W.F., \& Chretien, P.B. The effect of halothane on phytohemagglutinin-induced transformation of human lymphocytes in vitro. Anesthesiology 36: 206 (1972).

24. Bruce, D.L. \& Wingard, D.W. Anesthesia and the immune response. Anesthesiology 34: $271(1971)$.

25. LiNDE, H.W. \& BRUCE, D.L. Effects of chronic exposure of rats to traces of halothane. In, Progress in Anaesthesiology, Proceedings of the Fourth World Congress of Anaesthesiologists. London (1968) Excerpta Medica International Congress Series No. 200, p. 923.

26. BRUCE, D.L. \& KoEpKE, J.A. Interaction of halothane and radiation in mice: possible implications. Anesth. Analg. 48: 687 (1969).

27. LINDE, H.W. \& BRUCE, D.L. Occupational exposure of anesthetists to halothane, nitrous oxide and radiation. Anesthesiology 30:363 (1969).

28. Bruce, D.L. \& KoepKe, J.A. Clinical implications of the effect of halothane on depressed rat bone marrow. Anesthesiology 34: 573 (1971).

29. Bruce, D.L. Anesthetic management of patients with bone marrow failure. Anesth. Analg., in press.

30. Cartwright, G.E., Athens, J.W., \& Wintrobe, M.M. The kinetics of granulopoiesis in normal man, Blood 24: 780 (1964).

31. Bruce, D.L., Eide, K.A., Linde, H.W., \& Eckenhoft, J.E. Causes of death among anesthesiologists: a 20-year survey. Anesthesiology 29: 565 (1968).

32. Pierce, J.C., Madge, G.E., Lee, H.M., \& Hume, D.M. Lymphoma, a complication of renal allotransplantation in man. J.A.M.A. 219: 1593 (1972).

33. Whitcher, C.E., Cohen, E.N., \& Trudeld, J.R. Chronic exposure to anesthetic gases in the operating room. Anesthesiology 35: 348 (1971).

34. Priestley, W.O. \& Storer, H.R. (Eds.). The obstetric memoirs and contributions of James Y. Simpson, M.D., F.R.S.E. Philadelphia: Lippincott, Vol. 2 (1856), p. 663.

35. HENDERSON, Y. \& HAGGARD, H.W. Noxious gases and the principles of respiration influencing their action. New York: Reinhold, 2nd ed. (1943), p. 213.

36. Weiskotten, H.G., GibBs, C.B.F., Boggs, E.O., \& Templeton, E.R. The action of benzol. VI. Benzol vapor leucopenia (Rabbit). J. Med. Res. 41: 425 (1920).

37. Schrenk, H.H., Yant, W.P., Pearce, S.J., Patty, F.A., \& Sayers, R.R. Absorption, distribution and elimination of benzine by body tissues and fluids of dogs exposed to benzene vapor. J. Indust. Hyg. Toxicol. 23: 20 (1941).

38. Hamilton, A. Benzene (Benzol) poisoning. Arch. Path. 11: 434; 601 (1931).

39. EnF, L.A. \& Rhoads, C.P. The hematological effects of benzene (Benzol) poisoning. J. Indust. Hyg. Toxicol. 21: 421 (1939).

40. Das, K.C., Sen, N.N., Chatterjee, J., \& Aikat, B.K. Some observations on benzeneinduced hypoplastic marrow in tissue culture. Indust. J. Med. Res. 51: 890 (1968).

41. Mallory, T.B., Gall, E.A., \& Brickley, W.J. Chronic exposure to benzene (Benzol). III. The pathologic results. J. Indust. Hyg. Toxicol. 21: 355 (1939). 